Bangl. J. Vet. Med. (2009): 7(1) : 293 - 295

\title{
PREVALENCE OF ASCARIASIS IN VILLAGE POULTRY AT FIVE UPAZILAS UNDER FENI DISTRICT
}

\author{
R.R. Sarker ${ }^{1}$, M.Mostofa ${ }^{1}$, M.A. Awal ${ }^{1}$, M.S. Islam² ${ }^{2}$ and S.A. Mamun \\ ${ }^{1}$ Department of Pharmacology, Bangladesh Agricultural University, Mymensingh-2202, Bangladesh \\ ${ }^{2}$ Department of Medicine,Surgery and Obstetrics. Hajee Mohammad Danesh Science and Technology University, \\ Basherhat, Dinajpur-5200.
}

\begin{abstract}
The experiment was conducted at the Department of Pharmacology, Bangladesh Agricultural University, Mymensingh, during the period from July 2005 to November 2006 to study the prevalence of Ascariasis in village poultry at five upazilas of Feni district in Bangladesh. Survey was conducted on 200 village poultry. Highest prevalence of Ascariasis was recorded in Daganbhuiyan upazila (90.47\%) and lowest was in Parshuram upazila (81.57\%) and the infection rate on the basis of age was recorded at the age of 2-4 months.
\end{abstract}

Key words: Prevalence, ascariasis, village poultry

\section{INTRODUCTION}

The economy of Bangladesh is agro-based. Agricultural generated 39\% of the GDP of which the contribution of livestock sub-sector comes about 28\% (Brammer, 1996). .In the rural areas of Bangladesh and many other countries more than $60 \%$ families rear poultry. Assessment of the impact of traditional systems on poultry parasites has neither been attempted so far, nor there did any organize approach at present in Bangladesh.

Intensive case studies on individual households, was carried out in ten villages of five upazilas of Feni district namely Chhagalneya, Daganbhunya, Feni sadar, Parshuram and Sonagazi. The chicken production system in each village has been described and the problems were discussed. More than 60\% of the families kept chickens, and in most cases the women owned and managed the birds and controlled the cash from the sales. The production systems followed were mainly low-input and small-scale, with 7-10 mature birds per household, reared in the back yards with inadequate housing, feeding and health care. The average egg production per clutch was 15-20, with 3-4 clutches per year. The flock composition, price of poultry and poultry products, disease outbreaks and hatching of chicks were strongly affected by season. Disease was cited as the most important problem by most of the members of the community, followed by predation, lack of feed, poor housing, insufficient water and parasites. Considering all these points present research work was designed to observe the prevalence of Ascariasis in village poultry of Feni district.

\section{MATERIALS AND METHODS}

The experiment was conducted at the Department of Pharmacology, Bangladesh Agricultural University, Mymensingh, during the period from July 2005 to November 2006. To complete the research work following steps was followed:

\section{Survey the incidence of Ascariasis}

A total number of 200 village poultry were examined ranging from 2 months to 1 year of age from different villages of Chhagalnaiya, Daganbhuiyan, Feni Sadar, Parshuram and Sonagazi Upazila of Feni district. Prevalence was recorded on the basis of (a) Incidence rate in different Upazilas of Feni district and (b) Age-wise infection rate.

To study the prevalence, fecal samples were collected from the chicken in sample vials (containing formalin as preservatives) early in the morning. Collected samples were brought to BAU for laboratory examination. Direct smear and improved McMaster method were used for fecal examination.

\section{Fecal egg counts}

For determinations of infectivity, fecal samples were collected and eggs were counted by direct smear method and egg counting improved Mc Master method under the microscope in the Parasitology laboratory of BAU. 


\section{R. R. Sarker and others}

Parasite count by post mortem examination

Forty (eight chickens from each upzilla) chickens were slaughtered for post mortem examination to count number of parasites (Ascaridia galli).

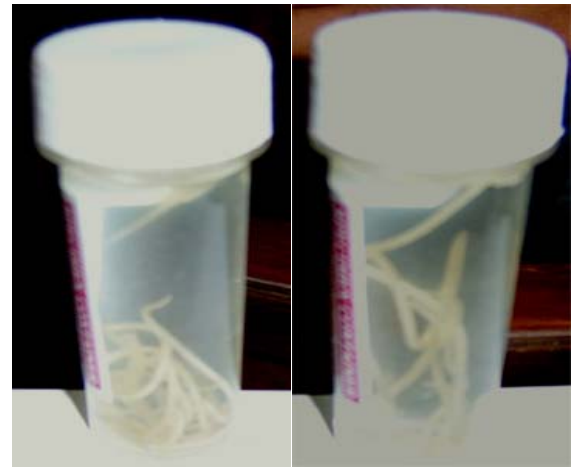

Fig. 1. Ascaridia galli in sample vial

\section{Statistical analysis}

The data were analyzed statistically between control and treated groups of fowls by the well known Student's test (t’test).

\section{RESULTS AND DISCUSSION}

\section{Prevalence}

The proportional incidence of Ascariasis in Village poultry chicken from 2 months to 1 year of at different Upazilas of Feni district is summarized in Table-1. The highest $(90.47 \%)$ and lowest (81.57\%) proportional incidence of Ascariasis was recorded in Upazila Daganbhuiyan and Parshuram respectively. However, the prevalence in Upazilas-Chhagalnaiya, Feni Sadar and Sonagazi, were varied from $82.22 \%$ to $88.57 \%$. From the Table-1, it was found that there was a variation in the proportional incidence rate of the infection among different Upazilas.

Table 1: Proportional incidence of Ascariasis in Village Poultry of different Upazilas of Feni district

\begin{tabular}{|l|l|l|l|}
\hline Name of the Upazila & No. of poultry examined & No. of poultry infected & Infection rate (\%) \\
\hline Chhagalnaiya & 35 & 31 & 88.57 \\
\hline Daganbhuiyan & 42 & 38 & 90.47 \\
\hline Feni Sadar & 40 & 35 & 87.50 \\
\hline Parshuram & 38 & 31 & 81.57 \\
\hline Sonagazi & 45 & 37 & 82.22 \\
\hline
\end{tabular}

The rate of infection was $90 \%$ in $2-4$ months of age, $80 \%$ in $4-8$ months of age and $86 \%$ in $8-12$ months of age of village poultry. In our country, more or less similar prevalence of gastro-intetinal nematodiasis in fowls have been reported earlier by Ahmed (1965) and Islam and Shaikh (1967). 
In aboard more or less similar prevalence of gastro-intestinal nematodiasis in fowls have also been recorded which was supported by Birova volasinovicova V(1963), Wakeline (1964), Norton (1964), Durrani and Chauhan(1965), Kaushik and Deorani(1968), Busa and Hernandez(1970), Korchagin(1974), Ssenyonga (1982).

In Bangladesh, however no countrywide survey to assess economic losses due to different gastrointestinal parasites have been carried out but it can easily be assumed that, losses due to gastrointestinal nematodiasis in chicken is very high. Nemeseri (1968) reported that about 40 millions chickens were infected with Ascaridia galli in Hungary, causing an annual economic losses equivalent to six millions U.S. dollars approximately. Katara and Rai (1980). From the above study it was evident that management and age factors played an important role in Ascariasis in poultry. This is why control program should be given priority.

Proportional incidence of Ascariasis in Village poultry of various age groups of 60 days to 1 year is shown in Table-2 and. Rate of infection was al most same in different age groups of poultry. The range of infection rate was 80 to $90 \%$. The highest rate of infection was found in 2-4 months of age group. Similar finding have reported by Romanenko (1985) and Haider et al. (1980).

Table 2: Proportional incidence of Ascariasis at various age groups of village poultry

\begin{tabular}{|l|l|l|l|}
\hline & $\frac{\text { Category-1 }}{2-4 \text { months }}$ & $\frac{\text { Category-2 }}{4-8 \text { months }}$ & $\frac{\text { Category-3 }}{8-12 \text { months }}$ \\
\hline No. of poultry examined & 80 & 70 & 50 \\
\hline No. of infected poultry examined & 72 & 56 & 43 \\
\hline Infection rate (\%) & 90 & 80 & 86 \\
\hline
\end{tabular}

\section{REFERENCES}

1. Ahmed R (1965). Animal Parasites and Parasitism. A report published by Mohakhali Animal Husbandry Research Institute Dhaka, East Pakistan.

2. Birova volasinovicova V (1963). Helminth hrabocej ich vyackyt to vdl,kochovochav, malochovoch. Veterinary medicine, Prague, 36:4, 229-230., Consolidated from the Helminthological Abstract, 33(2): 107.

3. Brammer H, Azaduzzaman M and Sultan R (1996). Effects of climate and sea level changes on the natural resources of Bangladesh. In the Implication and Climate and Sea Level Changes for Bangladesh. ( Warrick \& Ahmed QK eds), pp 143-203. Kluwer Academic Publisher.

4. Busa V and Hernandez NL(1970) Ecology Biology and Epizootiology of helminths of the domestis fowl. Revista Cubana de ciencias veterimarias. 1: 41-59. Heminthological Abatract vol. 41(9). Abstract No.2827.

5. Durrani MZ and Chauhan AH (1965). Data on the incidence of intestinal parasites of poultry in Lyalpur district proc. $16^{\text {th }}$ All Pakistan science conference. A-68.

6. Haider SS, Shaikh ALL, Saeed MM and khan TM (1980). A study on the helminthes parasite of broiler chicken in and around Lahore, Pakistan Journal of science 32 (1-2): 44, 46

7. Islam AWMS and Shaikh $\mathrm{H}$ (1967). A survey of helminthes in the gastro-intestinal tract of domestic fowls in Mymensingh district, East Pakistan. Ceylon veterinary Journal.15(3): 107-109.

8. Katara R.P and Rai,P. 1980. Comparative weight gain between experimentally infected chick with Ascaridia galli and uninfected growing chicks. Veterinary Research Journal. 3: 28-31.

9. Kaushik RK and Decoranj VPS (1968). Studies on helminth infection of poultry in Uttar Pradesh in India. Ceylon Veterinary journal 16(2): 56-58.

10. Korchagin AI (1974). Helminthological assessments of rearing and keeping methods on industrial and breeding poultry farms. Skryabina 21,119-127.

11. Nemeseri,L. (1968). Ujabb lehetosegek a baromfi- orsofergesseg elleni Kuzdelemben Parosit hung 1(1): 141-147 helminthological Abstract Vol. 39(9) Abstract No. 3485

12. Norton CC (1964). A survey of nematodes from the lower digestive tract of domestic fowls. Journal of Helminthology. 38: 269-282.

13. Romanenko PT, Troenko TA, Zaremba IA and Kuzyakin AV (1985). Age variation in helminth infection on chicken farm and factory faems in the Roostov region. Poultry Abatract 11(10): 249-250.

14. Ssenyonga GSZ3 (1982). Prevalence of helminthes parasites of domestic fowls in Uganda. Tropical Animal Health and Production 14(4): 201-204.

15. Wakeline D (1964). A survey of the Intestinal helminthes parasitic infection in British domestic fowls. Journal of Helminthology 38(1): 191-200. 